\title{
Mircea cel Bătrân, a Symbol of the Dobrogean Consciousness
}

\author{
Lecturer Edith-Hilde Kaiter, $\mathrm{PhD}^{1}$, Captain (N) Eng. Ioan Gabriel Moise ${ }^{1}$ \\ "Mircea cel Bătrân” Naval Academy, Constanța, Romania
}

\begin{abstract}
As the historical sources inform us, Mircea cel Bătrân had an extremely important influence in Dobrogea, being the ruler who managed to unite Dobrogea and Wallachia. While the Ottoman Empire was kept at a distance, the Romanian Voivode, as a good administrator and strategist, fortified Dobrogean fortresses and cities such as Isaccea, Enisala, Caliacra and Silistra. The discoveries of monetary treasures, consisting of coins dating from the time of Mircea cel Bătrân, spread throughout Dobrogea, prove the prosperity of the province during the time of the great Voivode, achieved through the intense trade of goods that took place and the important role the Romanian currency played in trade.

The hereby paper presents the importance of the reign of Mircea cel Bătrân for Wallachia and Dobrogea, in economic, cultural and social terms. The figure of the great Romanian ruler remains in the consciousness of the Dobrogean descendants through several educational institutions in Constanța that proudly bear his name.
\end{abstract}

Keywords: ruler, Dobrogea, faith, progress, freedom.

"Prince among Christians, the most brave and the most agile," as he was referred to by the German historian Johannes Leunclavius - who lived in the $16^{\text {th }}$ century and wrote a history of the Ottoman Empire, in which the author brings valuable information about the history of the Romanian Countries in the $15^{\text {th }}$ and $16^{\text {th }}$ centuries, Mircea cel Bătrân (also referred to as Mircea 


\section{Technium Sustainability}

the Elder) is one of the most representative figures of the Romanian history following his three decades of his reign, in which, being extremely courageous, he defended the country's statehood and religion in an attempt to form the bloc of Romanian unity.

The name of the great Voivode and Wallachian ruler remained consecrated in the historiography and in the consciousness of the Romanian people. His name, translated as "Mircea the Elder" (deriving from ancestors, from the past), lost its original meaning in the process of the evolution of the Romanian language. The byname "the Elder" (in Slavic: starîi) generally presupposes in the language of medieval Chancellor the first ruler known to have this name. As in Wallachia it was not used to number the rulers as in the West, so Mircea was given this Postum name to be distinguished from Mircea Ciobanul (the Shepherd), who ruled in the $16^{\text {th }}$ century. Mircea was also called "Mircea the Great" for his achievements and the nobleness of his character. (Panaitescu, p. 50)

After the death of his step-brother Dan I, Mircea takes over the throne on September 23, 1386, as Wallachia, on one side, was going through a process of economic, administrative, religious development, but also of strengthening the army, and on the other side it was confronted with the expansion tendencies of the Hungarian Kingdom and Poland, which were aiming at controlling the mouths of the Danube, but also those of the Ottoman Empire in the Balkans.

In order to cope with the threats of the Ottomans, Mircea cel Bătrân maintained good neighbourly relations with the kings and tzars in the south region of the Danube. (Panaitescu: P. 38) The great Wallachian Voivode manages to defeat the Ottoman troops in the Dobrogean garrisons and in 1388 he allots for the first time in history Dobrogea to Wallachia. (Panaitescu: P. 254-258) The wise ruler will keep Dobrogea until 1396, when in Nicopole he is defeated by Baiazid, known as the Flash. The sultan passes the Danube River and manages to remove Mircea from the throne. He takes refuge in the mountains, in Transylvania and in 1404, with the help of Sigismund of Luxembourg, he manages to recover Dobrogea, returning as ruler. In 1409, Mircea rejects a new attack of the Ottomans near Silistra, an important event recorded in a commemorative inscription in Greek language, discovered in this locality: "I, faithful to Christ and believer in God, I, Mircea, great Voivode and Lord by God's mercy and God's gift, ruling over all the land of Ungrovlahia and the parts over the mountains, even towards the Tartar parts and those of Amlaș 


\section{Technium Sustainability}

and Făgăraș and ruler of Severin Banat, and on both sides of Podunavia, still to the great sea and ruler of the fortress of Dârstor.” (Pippidi: P. 323-332)

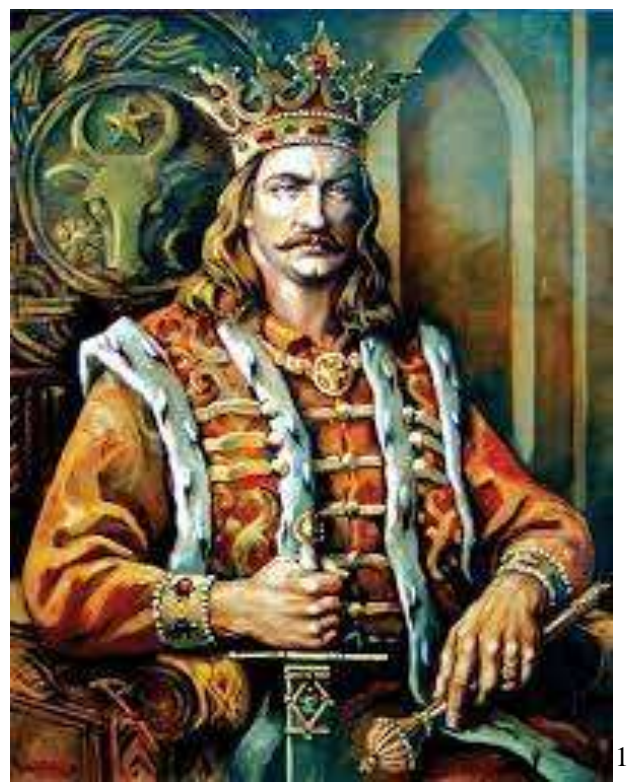

Mircea dies in 1418 and in 1420, the death of his son Mihail I leads to the loss of the right over Dobrogea, which will become part of the Ottoman Empire. Dobrogea manages to survive a long period of fighting and conquest until the War of Independence in 1877, when, as a result, Dobrogea becomes part of the Romanian administration.

The importance of the reign of Mircea cel Bătrîn for Wallachia cannot be overlooked. Even if the dominations over the Danube, Podunavia, Silistra and Dobrogea were not long-lasting, they marked the maximum territory run by a Romanian ruler up to Mihai Viteazul.

Regarding the internal politics, the great Wallachian ruler pursued, by means of important measures, the internal consolidation of the country in order to resist the threats of foreign powers. To this end, Mircea paid attention to the consolidation of the economy by measures on the tax system, by issuing coins in sufficient quantities and with appropriate values, as well as by stimulating trade with neighbouring countries with which he concluded treaties. Of course, other measures adopted by the ruler can also be mentioned: he introduced the feudal priority system, established material obligations for free and independent peasants, offered tax exemptions for church representatives and for those who provided military services, took measures to protect the

\footnotetext{
${ }^{1}$ https://www.google.com/search?q=mircea+cel+batran
} 


\section{Technium Sustainability}

land, organized the administration, the church, and endowed the army with weapons made by the Saxons from Transylvania. He set up a defensive system by building and consolidating some fortresses on the Danube, Turnu-Giurgiu, in Dobrogea, Silistra-Dârstor and inside the country, Breaza-Severin-Dâmbovița.

From a cultural point of view, a special merit of the ruler is the constant concern for the flourishing of church life and the development of spirituality. The involvement of the great ruler in the life of the Orthodox Church is largely justified by the fact that it was considered a reliable ally in the fight for the maintenance and strengthening of state independence, a fundamental objective of its policy. As a result of the Voivode's interest in preserving and strengthening the Orthodox Church in Transylvania, in 1401 Antim is awarded the title of "exarch of all Hungary and of the Places" by the Ecumenical Patriarchy, which means that the Romanian Metropolitan was also the patriarchal representative or delegate of the Orthodox Church in Hungary. Again, in Transylvania, at the initiative of St. Nicodim from Tismana, his counsellor regarding "God matters", the ruler agreed with the construction of Prislop Monastery. During the rule of Mircea cel Bătrân, there was a special concern for the construction and reorganization of churches and monasteries, the restoration and endowment of old churches or the construction of other settlements meant to strengthen the faith and maintain the unity of the Romanians in the provinces controlled. In time, many of the monastic sites that the ruler established, became centers of culture through the high activity of the copyists and calligraphs, as well as the creation of religious painting schools. For this purpose, the monastic centers of Vodita (Mehedinti), Tismana (Gorj), Vișina (Gorj), Cotmeana (Arges), Brădet (Argeș), Dealu (near Târgoviște), Snagov (near Bucharest), Polovragi (Gorj) can be mentioned, beside many others. The special interest of the country's Church led the ruler to allocate important material resources to the Metropolitan of Târgoviște and also to help the churches of Silistra ("St. Parascheva”), Niculițel (“St. Atanasie”), Enisala and Murighiol, tradition prayer tofts for the spirituality of the Romanian nation. The name of the Wallachian ruler is closely linked to the restoration work of Curtea de Argeș monastery and the old constructions of the Bucharest fair, but he did not neglect either the villages or the cities, to which he built or gave mercy for the chrism churches: Drobeta-Turnu Severin, Curtea de Argeș, Câmpulung, Râmnicu Vâlcea ("St. Parascheva”), Brașov ("St. Nicolae” - Șchei) and Hârtiești (Argeș). 


\section{Technium Sustainability}

In the series of these churches and monasteries, a special place is occupied by Cozia monastery, which was built during the reign of Mircea cel Bătrân in 1836, at the request of Saint Nicodim from Tismana, Mircea's confessor. The first school of copyists and calligraphers in Wallachia was set up here, and also, Filotei, who was the first Romanian to compose hymns as well as the great boyar of Wallachia, lived here. There were also numerous monks, but also important people of great culture, who later on held important positions.

According to a legend on the origin of the monastery construction, it is known that the Voivode Mircea cel Bătrân, during a war started against Hungarians (or against the Ottomans according to other historical sources), would have settled with his army on the Olt River Valley in a place called "Bivolaru". While sleeping in his tent on the lawn in front of the mountain, the Voivode would have had a dream, in which a "divine appearance" would have occurred, and the next day the Voivode would have decided to build a monastery there.

For the Wallachian ruler, Dobrogea's trade had always been a point of interest and connection with Wallachia and Moldova. In this area, the economic life depended largely on the basic occupations of the population, such as shepherding, and here we mention sheep farming, fishing, sea trade with wheat, oil, honey and wine. A definite proof of the local economic prosperity during the reign of Mircea cel Bătrân is represented by the numerous monetary treasures that belonged to Mircea or Petru Mușatin, found in Silistra, Niculițel near Isaccea, Enisala and Ecrene. (Panaitescu: P. 258)

It is necessary to mention that after the conquest of Dobrogea, Mircea cel Bătrân kept the old local administration into place. The Dobrogean rulers were called "chefalia", a term of Greek origin which meant a kind of land governor who was chosen from the large landowners. In Dobrogea the term "chefalia" had the meaning of a city ruler. (Panaitescu: P.258) It is also significant that the great Voivode made donations of land to his boyars and to the monasteries (Panaitescu: P. 147), thus contributing to the consolidation of their power.

The long reign of the great Voivode, which has been made up of numerous historical attested facts, helps us to know and understand his personality. Coming to the throne in the midst of a Christian Balkan world, with developing countries and the end of the reign in the struggles with the pagans, the permanent changes that have taken place in the political context, such as the rise of Poland, the rise and fall in Hungary, the changes in the Ottoman Empire generated by 


\section{Technium Sustainability}

Baiazid's victory and defeat, the battles for the throne and the restoration of the Empire led to the emergence of difficult situations, which Mircea had to cope with and adapt accordingly, because the life and freedom of his country depended on the resolution of those situations. In this unstable and threatening political context, Mircea manages to establish the country's foreign policy, respecting his principles and desideratum. Surely, the great ruler could not have done all this, had he not been an energetic, brave, courageous, faithful and especially a lover of the Romanian land. His deeds throughout his reign set up a strong personality that we can find in the great leaders of the Romanian nation: an important fighter for Christianity who was alongside his political and spiritual Community, gatherer of Romanian land, in Făgăraș and Amlaș, in Dobrogea and in the plains of Chilia, but also a good Romanian organizer and householder, a protector for Moldova and Transylvania. Another important feature of the ruler was diplomacy, without which he could not have been able to cope with the difficult situations he faced in all his years of reign. Mircea was also a good innovator, who changed the customs system from natural economy to money; he also changed the ways of doing business by bringing traders from Poland; he created the copper mining industry, introduced the round currency in the country, established new fairs (Târgușorul) and created a national church, fundamentally changing the establishments of our church.

The figure of the great Romanian ruler remained in the consciousness of the Dobrogean descendants. A number of education institutions in Constanța such as "Mircea cel Bătrân” National College, the famous "Mircea cel Bătrân" Naval Academy, as well as an important artery of the county seat bear with respect and gratitude the name of the great ruler, as a symbol of his domination on the territory of Dobrogea. Last but not least, the name of the ruler was attributed to the only large A-class sailboat that Romania has had and which belongs to the Naval Academy, a sailboat which, for over 80 years, has been training the future officers of the Romanian Naval Forces. 


\section{Technium Sustainability}

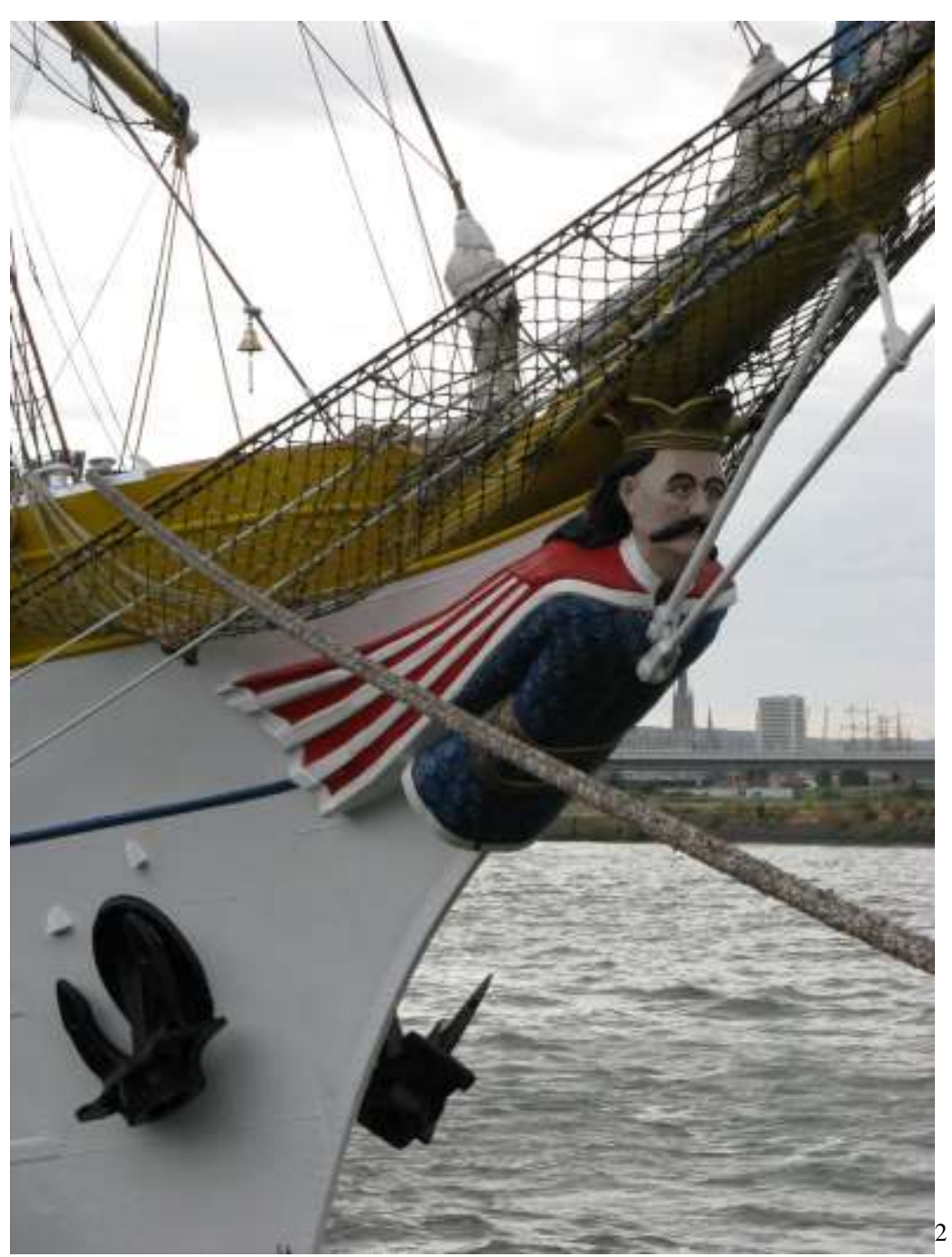

\section{BIBLIOGRAPHY}

[1] Analele Dobrogei Serie nouă An IV, nr. 1, Constanța, 1998.

[2] CONSTANTINESCU, Nicolae, Mircea cel Bătrân, Ed. Militară, București, 1981.

[3] GIURESCU, Constantin, Istoria Românilor, Ed. All Educational, București, 2003.

[4] LEUNCLAVIUS, Johannes, Annales sultanorum Othmanidarum a Turcis sua lingua scripti ... Francofurdi (Frankfurt): apud Andreae Wecheli heredes, Claudium Marnium, et Ioannem Aubrium, 1588.

\footnotetext{
${ }^{2}$ https://ro.wikipedia.org/wiki/Prov\%C4\%83\#/media/Fi\%C8\%99ier:Armada_Rouen_2008_DB_-_8.JPG
} 


\section{Technium Sustainability}

[5] MANEA Mihai, PASCU Adrian, TEODORESCU Bogdan, Istoria Românilor din cele mai vechi timpuri pâna la revoluția din 1821, Editura Didactică și Pedagogică, București, 1997, p. 231.

[6] PANAITESCU, Petre P., Mircea cel Bătrân, ediția a II-a, Editura Corint, București, 2000.

[7] PIPPIDI, Andrei, Sur une inscription grecque de Silistra, în Revue des Etudes Sud-Est Europeennes, XXIV, 1986, nr. 4.

[8] RĂDULESCU Adrian, BITOLEANU Ion, Istoria românilor dintre Dunăre și Mare Dobrogea, Ed. Științifică și Enciclopedică, București, 1976, p. 180-183. 